\title{
Fine-scale interactions between habitat quality and genetic variation suggest an impact of grazing on the critically endangered Crau Plain grasshopper (Pamphagidae: Prionotropis rhodanica)
}

\author{
Sylvain Piry',*, Karine Berthier 2,*, Réjane Streiff', Sandrine Cros-Artell ${ }^{3}$, Antoine Foucart ${ }^{4,5}$, Laurent Tatin ${ }^{6}$, \\ Linda Bröder ${ }^{7}$, Axel Hochkirch ${ }^{7}$, Marie-Pierre ChapuIS ${ }^{4,5}$
}

\begin{abstract}
1 CBGP, INRA, CIRAD, IRD, Montpellier SupAgro, Univ Montpellier, Montpellier, France.
2 Pathologie Végétale, INRA, 84140 Montfavet, France.

3 BGPI, INRA, Montpellier SupAgro, CIRAD, Montpellier, France.

4 CIRAD, CBGP, Montpellier, France.

5 CBGP, CIRAD, INRA, IRD, Montpellier SupAgro, Univ Montpellier, Montpellier, France.

6 Conservatoire d'espaces naturels de Provence Alpes Côte d'Azur, 13310 Saint-Martin-de-Crau, France.

7 Department of Biogeography, Trier University, D-54286 Trier, Germany.
\end{abstract}

Corresponding author: Marie-Pierre Chapuis (marie-pierre.chapuis@cirad.fr)

Academic editor: Corinna S. Bazelet | Received 13 July 2017 | Accepted 14 January 2018 | Published 12 June 2018

http://zoobank.org/9CE30A27-78C4-44EC-B68F-CFEB094B88DA

Citation: Piry S, Berthier K, Streiff R, Cros-Arteil S, Foucart A, Tatin L, Bröder L, Hochkirch A, Chapuis M-P (2018) Fine-scale interactions between habitat quality and genetic variation suggest an impact of grazing on the critically endangered Crau Plain grasshopper (Pamphagidae: Prionotropis rhodanica). Journal of Orthoptera Research 27(1): 61-73. https://doi.org/10.3897/jor.27.15036

\begin{abstract}
The Crau Plain grasshopper, Prionotropis rhodanica Uvarov, 1923 (Orthoptera: Pamphagidae: Thrinchinae), is a rare grasshopper species endemic to the Crau Plain, a steppic habitat in France with unique floristic and faunistic communities. During recent decades, the area covered by these steppic grasslands has been highly reduced and fragmented due to the development of irrigation-based agriculture, roads, as well as industrial and military complexes. The restricted distribution, low population density and poor dispersal ability of $P$. rhodanica, combined with the destruction of its habitat, has led to the classification of this species as critically endangered in the IUCN Red List of Threatened Species. Decreases in habitat quality due to intensive grazing in the remnant grassland patches constitute an additional threat for $P$. rhodanica that can impact population dynamics at a relatively small-scale. In this work, we focused on a small area of about $3 \mathrm{~km}^{2}$ occupied by one of the largest subpopulations observed in 2000-2001. We conducted a single-time snapshot intensive survey of grasshopper density and genetic variation at 11 microsatellite markers. We used a recent method, MAPI, to visualize the spatial genetic structure as a continuous surface and to determine, with the simultaneous use of spatial cross-correlograms, whether the normalized difference vegetation index, which informs on the balance between vegetation productivity and grazing intensity, can explain grasshopper population structure at such a fine scale. We found that both population density and gene flow were strongly and positively correlated to habitat quality (higher productivity of grasslands and/or lower sheep grazing). The spatial scales of interaction between these variables were estimated to be highly similar, in the range of 812-880 meters. This result suggests that $P$. rhodanica is very sensitive to the quality of the grasslands it inhabits.
\end{abstract}

\section{Key words}

conservation, grazing, landscape genetics, MAPI, NDVI

\section{Introduction}

The Crau Plain (Bouches du Rhône, France; Fig. 1A-B), the ancient delta of the Durance River, is the last arid steppe in France with a unique fauna and flora (Cheylan 1975, Devaux et al. 1983, Wolff et al. 2001, 2002, Romermann et al. 2005, Tatin et al. 2013). The characteristic vegetation of this steppe is called Coussoul and is mainly composed of Brachypodium retusum and Thymus vulgaris in association with Asphodelus fistulosus and Stipa capillata. This unique ecosystem has been maintained over 3,000-4,000 years by extensive sheep grazing (Buisson and Dutoit 2006, Tatin et al. 2013). Since the sixteenth century, and more intensely within recent decades, the plain has been highly modified by intensive irrigation-based agriculture (Devaux et al. 1983). The contraction of the Coussoul from $\sim 600 \mathrm{~km}^{2}$ to less than $100 \mathrm{~km}^{2}$ (Wolff et al. 2002) and its fragmentation by agricultural fields (orchards and hay meadows), irrigation channels and other artificial structures (roads, industrial and military complexes) threaten the natural habitat and its fauna. Since 2001, 7,400 ha of the Crau Plain have been protected as a national nature reserve and since 2010 a management plan has been implemented with conservation actions for its remarkable species. Among them, P. rhodanica (Fig. 2) is a large (between 30 and $50 \mathrm{~mm}$ ) grasshopper species endemic to the Crau Plain and protected in France (Anonyme 1979). This species has been classified as Critically Endangered in the IUCN Red List of Threatened Species (Hochkirch and Tatin 2016) as well as on the European Red List (Hochkirch et al. 2016) and the national Red List of France (Sardet and Defaut 2004). P. rhodanica is only known from the Crau Plain, though surrounding areas have been intensely surveyed. The species is generally considered as rare, ex-

equal contribution 

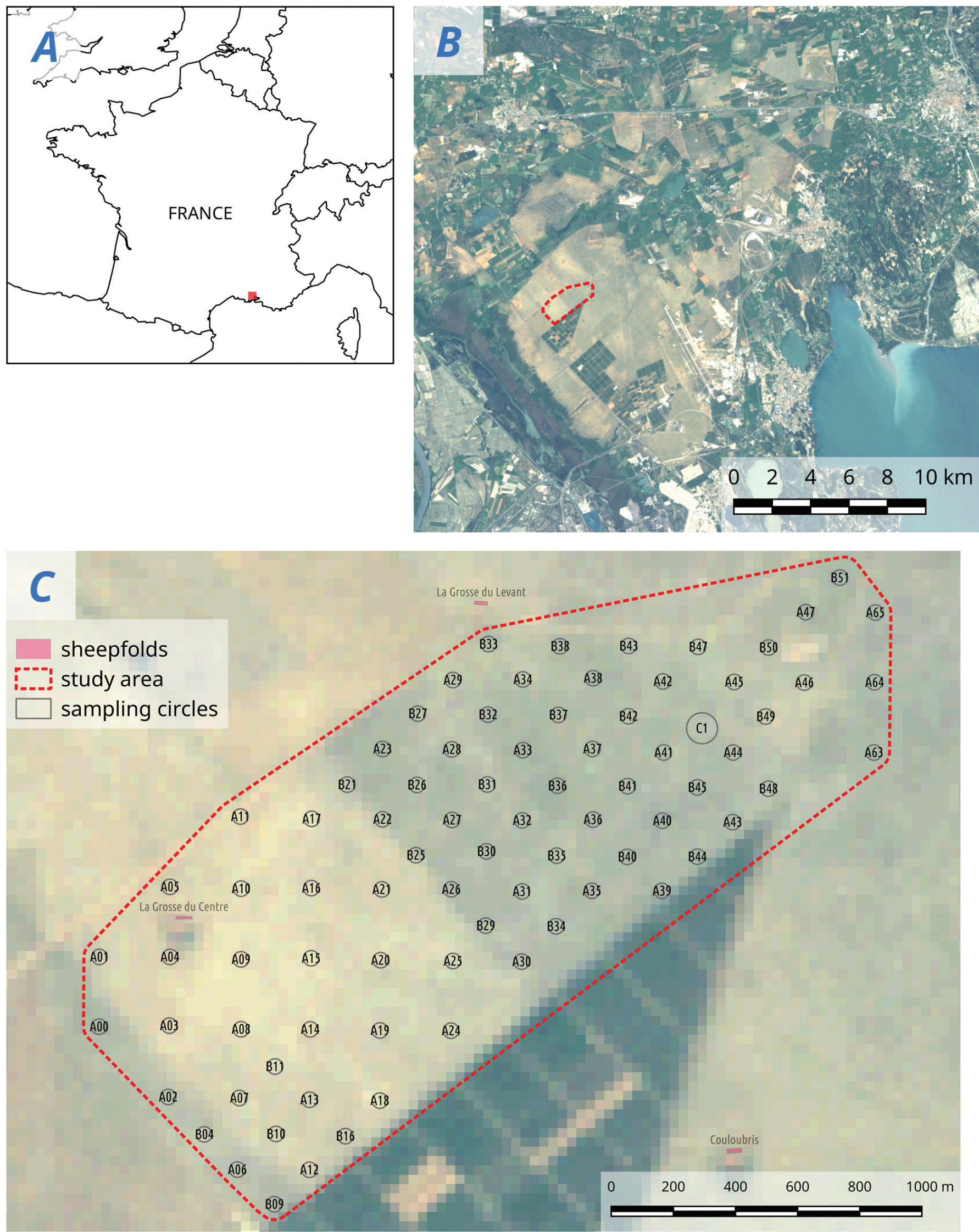

Fig. 1. Map of France and location of A. the plain of Crau (Bouches-du-Rhône, France), B. the sampling site located between the sheepfolds 'La Grosse du Levant' and 'La Grosse du Centre', and C. the circles surveyed to detect and sample P. rhodanica. A00-A65: names of circles of the grid A; B04-B51: names of circles of the grid B; C1: additional circle of 100 m diameter (see Material and methods). 


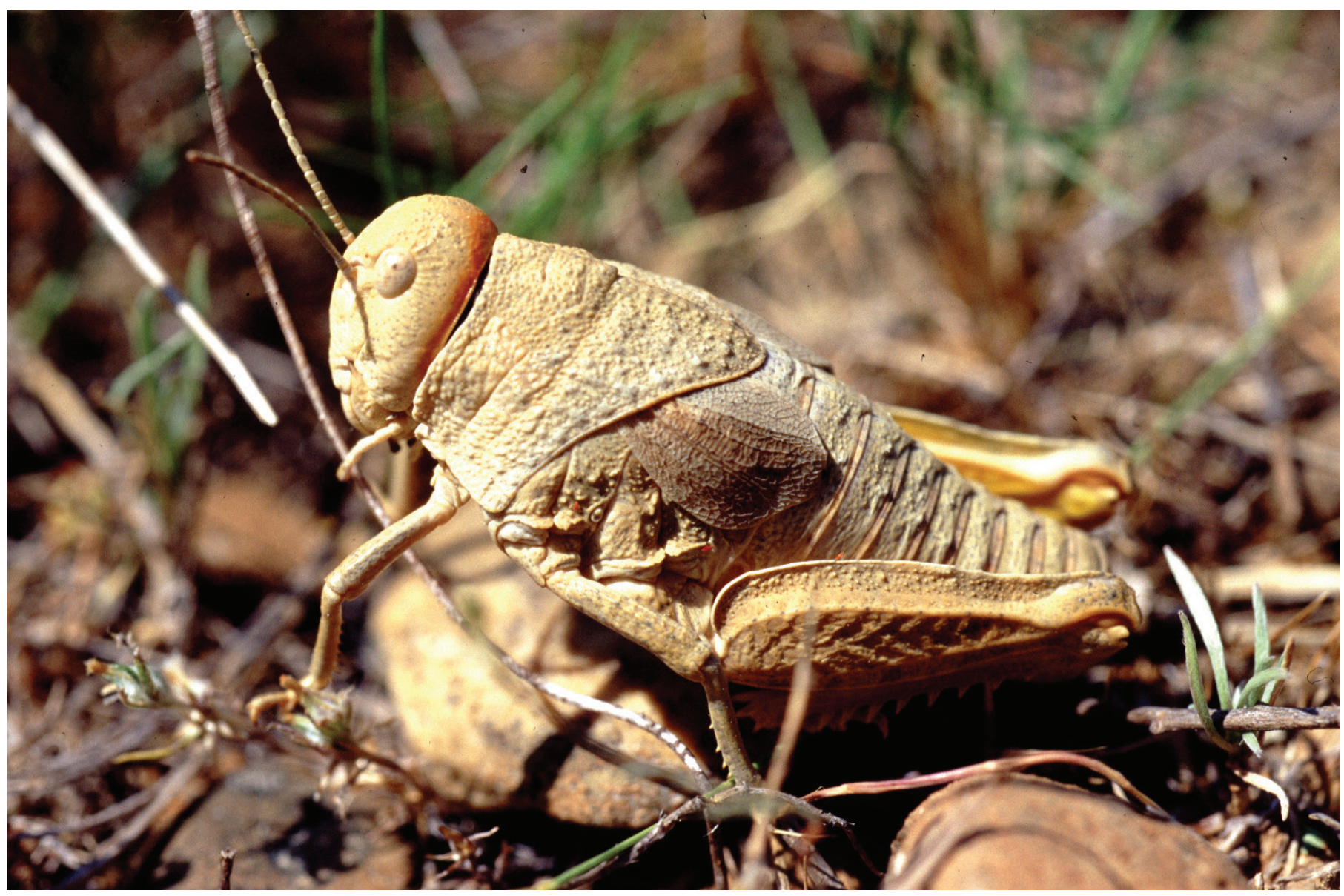

Fig. 2. Adult of Prionotropis rhodanica.

cept for some atypical years, and observations over the last fifteen years revealed an extreme decline in population densities along with local extinctions (Foucart and Lecoq 1996, Foucart et al. 1999, Hochkirch et al. 2014). In 2014, a conservation strategy for the species was developed under the guidance of the Species Conservation Planning Sub-Committee (SCPSC) and the Invertebrate Conservation Sub-Committee (ICSC) of the International Union for Conservation of Nature (IUCN) (Hochkirch et al. 2014). One main aim of the strategic conservation plan was to identify the reasons for the population decline.

Orthoptera are known to be highly sensitive to landscape alterations, such as those associated with farming, in terms of genetic diversity and structure (Ortego et al. 2012, Gauffre et al. 2015, Ortego et al. 2015) as well as population decline or extinction risk (Barker 2004, Reinhardt et al. 2005). However, demographic responses and evolutionary trajectories differ among species, and some species are more susceptible than others regarding the negative effects of habitat perturbations (Ortego et al. 2015). Thus, conservation practices in protected areas require detailed ecological and evolutionary information to target species that require particular attention and guide their management (Ortego et al. 2015). A capture-mark-recapture study conducted on $P$. rhodanica at a fine scale $\left(8,000 \mathrm{~m}^{2}\right)$ over a two-month period (May-June) in 2000 showed that individual movements occur over very short distances (mean distance between two captures $<20 \mathrm{~m}$ ) and suggested that adults are more mobile than nymphs (Berthier 2000, see also Besnard et al. 2007). These very limited dispersal abilities of $P$. rhodanica were expected as adults of both sexes are brachypterous and thus incapable of flight (Fig. 2; Foucart 1995, Foucart et al. 1999). Furthermore, studies of the genetic structure of $P$. rhodanica conducted on a small number of sample sites (2-5) and microsatellite loci (5) revealed that subpopulations are strongly differentiated even when located a few hundred meters apart (Berthier 2000, Streiff et al. 2005). These results suggest that $P$. rhodanica subpopulations are isolated with dispersal events among them being rare, confirming that biological and ecological characteristics of the species result in low demographic and genetic connectivity between isolated subpopulations. Isolation effects depend on the sizes of habitat elements, the distances between them and the quality of the surrounding matrix (Prevedello and Vieira 2010). Their quantification would thus be important to assess the species vulnerability to the reduction and fragmentation of its habitat and would require an intensive sampling of remnant subpopulations at a large scale (e.g. the complete geographic range of the species).

An additional threat for $P$. rhodanica might result from livestock grazing pressure (Hochkirch et al. 2014). While the available surface of Coussoul has continuously been decreasing for centuries, flock sizes fluctuate from one year to the next and can reach 1,600 sheep on average (Wolff et al. 2013). Moreover, the size of flocks can strongly increase when sheep are gathered to prepare for the transhumance in June-July, coinciding with the breeding period of $P$. rhodanica (Foucart and Lecoq 1996). For example, during the capture-mark-recapture study conducted in 2000, the size of the flock grazing the $3 \mathrm{~km}^{2}$ land plot within which our study site of $8,000 \mathrm{~m}^{2}$ was localized increased from 250 to 1,200 individuals in two months (Berthier 2000). Generally, such successive peri- 

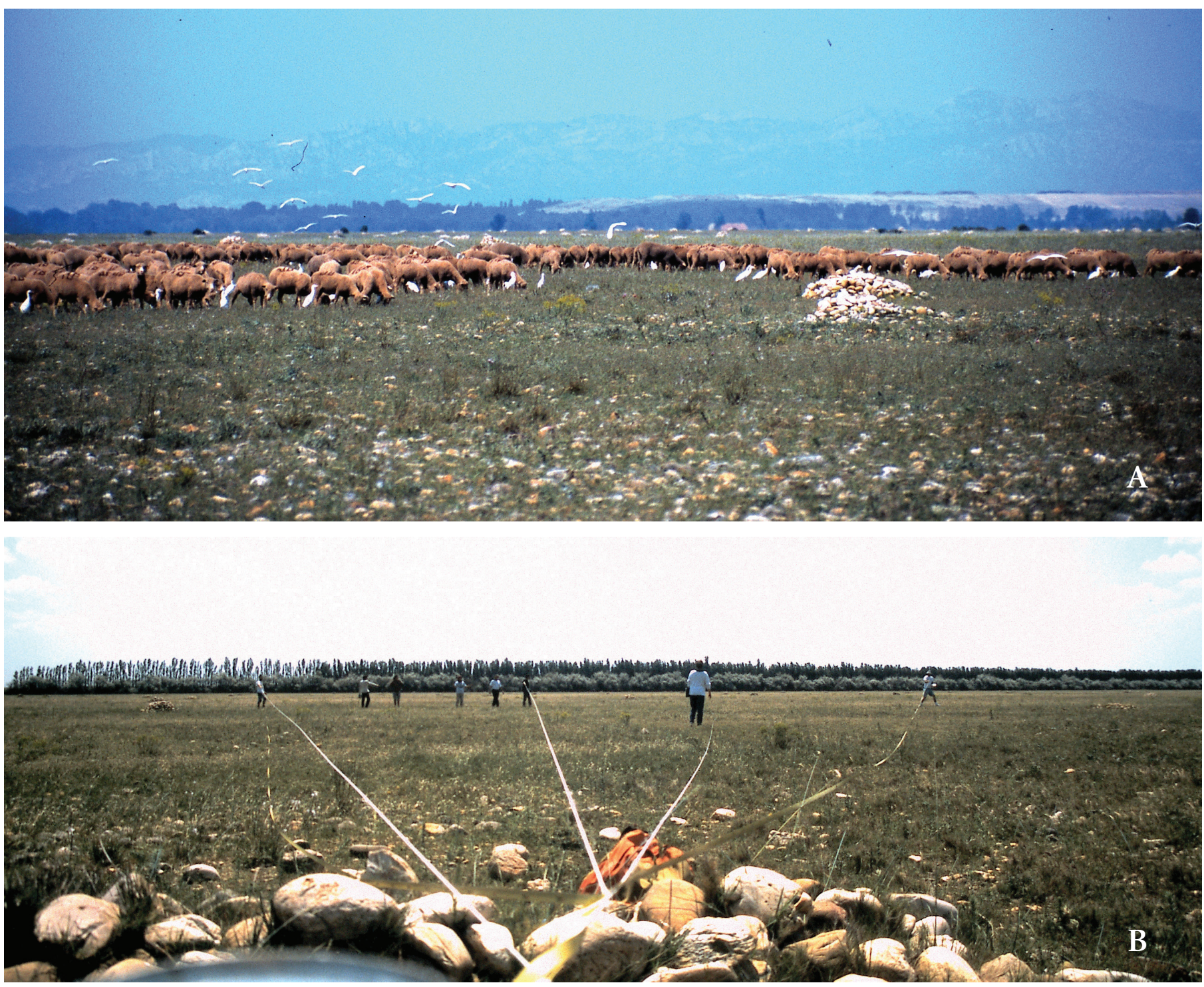

Fig. 3. Illustrations of the Coussoul habitat of Prionotropis rhodanica with A. sheep accompanied by cattle egrets and B. researchers surveying the species using a circle-based method.

ods of intensive grazing can be detrimental because they reduce primary productivity, impede plant growth and alter vegetation cover that provides the grasshopper with food and shelter. In $P$. rhodanica, the highest observed abundances were associated with a vegetation cover above $70 \%$ (Tatin et al. 2013). In addition to competition for resources, negative impacts of intensive grazing include trampling and predation by birds associated with sheep flocks (Hochkirch et al. 2014). In particular, the cattle egret, Bubulcus ibis L., often accompanies sheep flocks (Fig. 3A) and catches insect and small vertebrate prey disturbed by sheep (personal observation). Since pasture boundaries delineate plots less than 550 ha (min of 30 ha and mean of 168 ha), grazing pressure and consequently grasshopper habitat quality may vary at a relatively small scale in the Crau Plain, even within apparently continuous and favorable areas of Coussoul. Information on fine-scale spatial genetic structure would allow an assessment of the role of habitat quality, rather than that of unsuitable elements that isolate habitat patches, on contemporary dispersal patterns. However, a sampling scheme at a fine scale has never been attempted in $P$. rhodanica.
MAPI (Mapping Averaged Pairwise Information; Piry et al. 2016) is a new method for spatial visualization of population structure and investigating landscape effects. MAPI is essentially a smoothing procedure for spatial genetic networks, useful for large sample sets for which usual representations (i.e. nodes and edges) are often unreadable. MAPI can be applied to genetic differentiation measures computed from neutral markers (e.g. microsatellites) to detect areas of high genetic continuity and/or discontinuity that reflect areas where gene flow is the highest and/or the lowest, respectively. MAPI allows visualizing the spatial genetic structure as a geographic map that provides information on the average intensity of the genetic relationships, and can be exported simultaneously with landscape layers and density data for further statistical analyses. This exploratory approach may thus provide information on which environmental variables are potential candidates to explain observed genetic patterns. A central feature of MAPI is its low sensitivity to confounding effects resulting from isolation-by-distance (IBD). This is especially true in an ideal situation, with perfect regular sampling and no edge effects (Piry et al. 2016). However, when 
sampling is highly irregular, the insensitivity to IBD still holds relatively to clustering methods (Guillot and Santos 2009, Bradburd et al. 2013, Piry et al. 2016). This is a critical issue when assessing the impact of landscape heterogeneity on population genetic structure, which also depends on geographic distance (Bradburd et al. 2013). This may be of high relevance to $P$. rhodanica since significant IBD patterns have been reported at fine spatial scale $(2-10 \mathrm{~km})$ in other orthopteran species that are flightless (Lange et al. 2010, Keller et al. 2013, Gauffre et al. 2015), or considered to be sedentary (Ortego et al. 2011, Blanchet et al. 2012).

In this study, we focused on a small area of $2.87 \mathrm{~km}^{2}$ within which direct gene flow was likely to occur while potential effects of the physical landscape (i.e. barriers to dispersal, presence of inhospitable patches) were expected to be minimal. Our target study site was a suitable habitat for $P$. rhodanica but with potential variation in quality in particular due to sheep grazing regime. It was located in a large patch of Coussoul where the largest subpopulation of $P$. rhodanica was observed at the end of the nineties (Foucart et al. 1999). In spring 2001, we carried out a single-time snapshot intensive survey of grasshopper density and genetic variation at eleven microsatellite loci. The sampled subpopulation was composed of 266 individuals of a single cohort since $P$. rhodanica is univoltine with discrete generations (eggs hatch in early April and all adults die by mid-July; Foucart and Lecoq 1996). We investigated contemporary patterns of dispersal by first testing whether there is non-random spatial structure due to relatedness among individuals at the scale of the sampling unit (i.e. $\leq 50 \mathrm{~m}$ ) and/or isolationby-distance at the scale of the study area. We then used MAPI to produce a continuous variation surface of the genetic relationships between individuals. Finally, we used spatial cross-correlograms to quantify the spatial scales of interactions between this genetic pattern and variations in grasshopper density and habitat quality. To quantify small-scale variation in habitat quality in our study site, we used the normalized difference vegetation index (NDVI) as a proxy of the balance between vegetation productivity and vegetation degradation partly due to grazing. Remotely sensed vegetation indices are commonly used to monitor changes in vegetation and land cover, and their correlation with grazing intensity has been demonstrated in other parts of the world (e.g. Raynolds et al. 2015), including in semi-arid environments (Blanco et al. 2008, Karnieli et al. 2013). Here, the validity of the relationship between vegetation productivity, NDVI and grazing effect was evaluated in the specific area of the Crau Plain using data from a recent experiment (i.e. conducted in 2015).

\section{Material and methods}

Sampling and grasshopper densities. - P. rhodanica is particularly difficult to detect in the field (less than 10\% detection probability) due to its low mobility, cryptic coloration and crypsis behavior (Streiff et al. 2005, Besnard et al. 2007, Tatin et al. 2013). Therefore, we determined a sampling area of $2.87 \mathrm{~km}^{2}$ to focus on the zone where densities were relatively large in 2001 (Fig. 1B-C). Within the study area, circles with $50 \mathrm{~m}$ diameter were regularly distributed to create two completely overlapping grids (A and B), so that circles from grid A alternate with those from grid $\mathrm{B}$ every 160 meters (Fig. 1C). All circle centers were positioned using Global Positioning System (GPS). Grid A was entirely surveyed between the $21^{\text {st }}$ and $29^{\text {th }}$ of June 2001 to ensure a complete coverage of the study area. In grid B, only the circles located in zones where the species was detected in grid A were surveyed between the 27th to the 31 st of June 2001. In addition to the $50 \mathrm{~m}$ circles of grid A and $\mathrm{B}$, a circle with $100 \mathrm{~m}$ diameter located within the zone with the highest $P$. rhodanica density was also surveyed between the $21^{\text {st }}$ and $29^{\text {th }}$ of May 2001.

All circles were divided in 8 adjacent sectors (16 for the $100 \mathrm{~m}$ diameter circle), physically delimited in the field, and each sector was explored by three persons walking abreast and passing at least twice on a same path (Fig. 3B). For each insect observed, polar coordinates to the center were recorded, and then converted in latitude and longitude. Sex and developmental stage (nymph/adult) were recorded. A non-destructive sampling method was used for further genetic analyses (a small piece of elytra or tarsus was collected and the insect released at its capture position). From the 82 surveyed circles, a total of 266 individuals (213 nymphs, 53 adults, $132 \mathrm{fe}$ males and 134 males) were sampled. More than $50 \%$ of the circles (i.e. 44) did not contain grasshoppers and densities varied from 5.1 to 133.3 individuals per hectare within the 38 remaining circles (Suppl. material 1: Table S1). Accordingly, an analysis of the spatial distribution using Ripley's $K$ function revealed a patchy distribution of the individuals within the study area (Suppl. material 1: Fig. S1).

Microsatellite genotyping and basic genetic indices.-Genomic DNA was extracted following the CTAB protocol (Doyle and Doyle 1987). DNA concentration was determined using a Nano-drop spectrophotometer (NanoDrop Technologies, Wilmington, USA) and extracts were normalized to a concentration of ca. $5 \mathrm{ng} / \mu \mathrm{L}$. Eleven microsatellite loci were used, ten of which were previously described in Streiff et al. (2002) and Streiff et al. (2005) and one additional locus was developed for this study (see primer sequences in Suppl. material 1: Table S2). We genotyped the 266 individuals at the 11 microsatellites using an ABI PRISM 310 DNA sequencer (Applied Biosystems) using conditions described in Suppl. material 1: Table S2. Alleles were scored using GeneMapper 4.0 (Applied Biosystems).

The level of polymorphism and allelic distribution were estimated with GENEPOP v.4 (Rousset 2008). We first tested for linkage disequilibrium between each pair of loci and within each circle by using G-exact tests (keeping the 22 circles out of 38 non-empty circles with sampling size $\geq 3$ individuals). Over the sampling site, and for each locus, we tested for Hardy-Weinberg equilibrium using G-exact tests and estimated the number of alleles, observed and expected heterozygosities of Nei (1987) and Wright's F-statistic $F_{\text {IS }}$ according to Weir and Cockerham (1984). We also tested for genotypic differentiation among circles by using the exact G-test of heterogeneity of genotypic frequencies (keeping the 22 circles with sampling size $\geq 3$ individuals).

Kinship and isolation-by-distance patterns. - In order to analyze the relatedness structure at the circle scale, we calculated the kinship coefficient of Loiselle et al. (1995) between pairs of individuals belonging to a same circle, using SPAGeDI v.1.4 (Hardy and Vekemans 2002). We then used Spearman rank correlation to test whether there is an association between grasshopper density measures and mean values of kinship coefficient within circles.

We assessed whether dispersal was restricted with distance, using GENEPOP v.4 (Rousset 2008). We computed for each pair of sampled individuals, and over all loci, the statistics $\hat{a}$ (Rousset 2000), which is considered as an unbiased estimator of genetic distance (Watts et al. 2007). We used a Mantel test between the matrices of genetic distances $(\hat{a})$ and the logarithm of geographical Euclidean distances to test for a positive linear relationship as expected under an IBD model. We excluded pairwise comparisons between individuals separated by less than $75 \mathrm{~m}$ to exclude intracircle measures. This would limit the impact of siblings on the es- 
timation of the relationship between genetic and geographic distances. Confidence interval and significance of regression slope was calculated by bootstrapping over loci using 10,000 permutations. We also performed the same IBD analysis for each sex separately.

NDVI computation. - As suggested by Gan et al. (2014), we computed rescaled NDVI values by building fine-scale NDVI raster from Landsat images and calibrating the results using a coarseresolution MODIS raster. The LANDSAT 7/8 ETM+ raster $(30 \mathrm{~m}$ resolution) and NDVI MODIS raster, all courtesy of the U.S. Geological Survey, were downloaded from https://earthexplorer.usgs. gov. The MODIS NDVI is a 16-day composite of MODIS data at a spatial resolution of $250 \mathrm{~m}$. First, NDVI values were computed at the spatial resolution of the Landsat raster $(30 \mathrm{~m})$ using an updated version of the python script provided by Dr. J. Degener and available from https://www.uni-goettingen.de/en/524379.html. Second, the Landsat NDVI raster and the MODIS NDVI raster were clipped over the area of interest (projection UTM 31 / WGS84). Third, the MODIS NDVI raster was aligned on the Landsat NDVI raster using the nearest value. Both rasters were then loaded in the statistical software R (R Core Team 2015) using the packages "rgdal" and "raster" and, finally, the pixel values from both rasters were bound into a single dataframe. Pixels with missing MODIS values $(-3,000)$ were discarded from the dataset. MODIS NDVI values were divided by 10,000 to be within the range of the Landsat NDVI values. Landsat NDVI values were then normalized by performing a pixel-to-pixel regression of the MODIS NDVI values against the Landsat NDVI values (see Suppl. material 1: Figs S2, S3 for an illustration).

Relationship between NDVI, habitat quality and grazing.-We analyzed the relationship between rescaled NDVI, vegetation productivity and grazing using data from a recent experiment. In 20152016, an enclosure of 8.56 ha, located in the same area as our study site (Suppl. material 1: Fig. S4), was fenced between April and August to exclude sheep. One hundred plots (of $30 \mathrm{~cm}$ diameter each) were randomly selected to measure vegetation productivity indices within (50 plots) and outside (50 plots) this enclosure. Vegetation productivity indices included: vegetation height, coverage in forbs, coverage in dry vegetation and coverage in bare ground (i.e. no vegetation). We tested whether our four productivity indices reflected the impact of sheep grazing on vegetation using Wilcoxon tests to compare the measures between plots located inside and outside the enclosure. Rescaled NDVI values were computed from Landsat and MODIS images captured in May 2014 (before fencing) and May 2016 (after fencing). Each vegetation plot received the rescaled NDVI value of the $30 \mathrm{~m}$ pixel to which it belonged. We analyzed the relationship between 2016-rescaled NDVI values (after fencing) and the four vegetation productivity indices using Spearman rank correlations. Finally, we used Wilcoxon tests to verify that after fencing (2016) the rescaled NDVI values were, on average, significantly lower for the plots located inside the enclosure than outside, while no differences were expected for 2014-rescaled NDVI values (before fencing). In other words we tested that our rescaled NDVI was an appropriate proxy to assess grazing impact on grasshopper habitat quality. Statistical analyses were done using R (R Core Team 2015).

Spatial association between grasshopper density, habitat quality and genetic variation. - We used the MAPI program (Piry et al. 2016), freely available at https://www1.montpellier.inra.fr/CBGP/software/MAPI/. We produced a geographical map of the spatial vari- ation of the mean genetic differentiation between individuals and then interpolated, within the cells of the map grid, grasshopper density and habitat quality (rescaled NDVI) to test for correlations between variables. The successive three steps of this analysis are detailed below.

Map of genetic differentiation. - We attributed the values of the statistics $\hat{a}$ of Rousset (2000) to ellipses that spatially materialize the connections between the pairs of individuals. A grid of hexagonal cells with a half-width of $20 \mathrm{~m}$ was superimposed on the study area (cell's area $=1,040 \mathrm{~m}^{2}$; see 'Grid of cells' section in Piry et al. (2016) for details). Each cell received the weighted arithmetic mean of the ellipses intercepting its geographical extent. This mean was weighted using the inverse of the ellipse areas to limit long distance effects. MAPI values for the eccentricity of ellipses that controls the smoothing intensity was set by default (i.e. eccentricity $=0.975$ ). However, additional analyses were run with eccentricity values from 0.800 to 0.999 to assess robustness of MAPI results to the shape of ellipses (i.e. from inflated to narrow). The radius of the error circle that controls for uncertainty on sample polar coordinates (error_circle_radius) was set to $2 \mathrm{~m}$. An interesting feature of MAPI is the optional parameters that limit the analysis to a given range of between-sample distances. We used a minimum distance between samples (min_distance) of $75 \mathrm{~m}$ in order to exclude pairwise comparisons between individuals from a same circle. Details on parameters can be found in Table 1 and Suppl. material 1 from Piry et al. (2016) and in pp. 29-31 from the MAPI manual. Finally, to ensure that MAPI results were not biased by the patchy distribution of individuals (higher number of individuals sampled in high density areas), we ran the analysis on 100 independent resampled datasets with a maximum of three individuals from each circle and checked for consistency of results.

Density and NDVI spatial interpolation-Grasshopper densities measured within circles and rescaled NDVI values from Landsat (captured the 18 of May 2001: LE07_L1TP_196030_20010518_2 0170205_01_T1.tar.gz) and MODIS (captured the first 16 days of May 2001: MOD13Q1.A2001129.h18v04.006.2015142065654. hdf) images were first interpolated into a raster ( $5 \mathrm{~m}$ resolution) using the function "using v.surf.rst" of the GRASS software (GRASS Development Team 2012) with parameter values set as follows: maximum number of points in a segment $($ segmax $)=120$, minimum number of points for approximation in a segment (npmin) $=60$ and maximum distance between points on isoline $(\mathrm{dmax})=$ 25. Values interpolated below 0 were reset to 0 using the GRASS function "r.mapcalc". Second, raster pixels were clipped to MAPI grid cells and interpolated density values from pixels belonging to the same MAPI cell were averaged using the ST_SummaryStats function of the PostgreSQL 9.3 with the PostGIS 2.1.2 extension (1996-2016, The PostgreSQL Global Development Group: http:// www.postgresql.org/ - http://postgis.net/).

Spatial scales of association between variables. - Spatial cross-correlograms allow investigation of how two variables co-vary with geographic distance. We used the non-parametric spline-correlogram approach implemented in the R package "ncf" (Bjørnstad and Falck 2001) to analyze the spatial scale of association (Sp) between interpolated values of: 1) grasshopper density and rescaled NDVI, 2) grasshopper density and mean genetic differentiation between individuals (i.e. MAPI cell values) and, 3) rescaled NDVI and mean genetic differentiation between individuals (i.e. MAPI cell values). 
Confidence envelopes at $95 \%\left(\mathrm{CE}_{95 \%}\right)$ for the estimated correlograms were calculated using bootstrapping (500 replicates). We also computed Spearman rank correlation coefficients (Rho) between all pairs of variables.

\section{Results and discussion}

Thirty-four of the 1,210 tests for linkage disequilibrium between the 11 loci were significant after false discovery rate correction (Storey and Tibshirani 2003). Because these pairs of loci were never significant in more than two circles, all microsatellite loci were considered unlinked. We found significant deviations from Hardy-Weinberg equilibrium at the global scale for most loci and the $F_{\text {IS }}$ value averaged to 0.072 across loci (Table 1). Heterozygote deficits can be partly related to presence of null alleles for the few loci that show highest values (i.e. Phr7178 and Phr756 with a $F_{1 \mathrm{IS}}$ $>0.3$ ). Prevalence of null alleles has commonly been reported in studies documenting microsatellite variation in orthopteran populations (Zhang et al. 2003, Chapuis et al. 2005, Hamill et al. 2006, Berthier et al. 2008, Chapuis et al. 2008). However, the heterozygote deficit concerns most loci, which suggests that it primarily results from spatial structure (i.e. Wahlund effect) rather than presence of null alleles. As a matter of fact, global genetic differentiation between circles was highly significant $(P<0.0001)$ and all pairs of circles were significantly differentiated $(P \leq 0.001)$. Moreover, most of the Loiselle kinship coefficient values averaged within circles were positive. Thus, pairs of individuals within circles were more related than expected under random distribution of genotypes. This pattern at a scale of $50 \mathrm{~m}$ confirmed the limited dispersal capacities of this flightless grasshopper species, at least at the nymphal stage.

The levels of genetic diversity were high, with a mean expected heterozygosity of 0.813 and an average of 16.18 alleles for our sample size of 266 individuals (Table 1). They are similar to the levels of genetic diversity observed by Berthier (2000) and Streiff et al. (2005) within subpopulations of the same species. The (apparent) lack of impact of habitat modifications on the level of genetic diversity may be explained by their recentness in the Crau Plain (Streiff et al. 2005). Changes in genetic diversity after a perturbation are related to the total effective population size, and show slow dynamics with non-equilibrium states over large temporal scales. This result may also account for the limited dispersal in the fragmented population of $P$. rhodanica, which allows for strong differentiation between subpopulations and thereby a high level of total genetic diversity (Nei 1973). Beside population demography and history, this outcome may also result from the high microsatellite loci mutation rate, which has been confirmed for the Orthoptera (Chapuis et al. 2012). Overall, P. rhodanica did not seem to be affected by a low level of genetic diversity, which is widely recognized as a major impediment for the adaptation of a population to environmental changes. However, this does not preclude that the species may have a low total population size, which would make it vulnerable to demographic stochasticity that can lead to local extinctions (Frankham 2005). Indeed, during a standardized survey conducted in 2012-2013, P. rhodanica was not detected in our study site anymore and this subpopulation is now assumed to be extinct (Hochkirch et al. 2014).

We detected a significant negative relationship between the Loiselle kinship coefficient and density within circles $($ Rho $=$ -0.59 ; $\mathrm{p}$-value $=0.0012$; Fig. $4 \mathrm{~A}$ ), i.e. the lower the grasshopper density, the higher the genetic relatedness. Since we did not find any evidence for lower levels of genetic diversity within lower
Table 1. Genetic diversity indices for each of the 11 loci from $P$. rhodanica. Number of alleles (Na), Wright's F-statistic $F_{\text {IS }}$ and observed (Ho) and expected (He) heterozygosities were averaged over the 266 individual samples.

\begin{tabular}{cccccc}
\hline Locus & Na & $F_{\text {Is }}$ & Ho & He & $\begin{array}{c}\text { HW test } \\
P \text { value }\end{array}$ \\
\hline Phr1C7 & 23 & 0.034 & 0.865 & 0.895 & $<0.0001$ \\
Phr228 & 9 & 0.028 & 0.545 & 0.561 & 0.1770 \\
Phr2C3 & 10 & 0.015 & 0.816 & 0.828 & $<0.0001$ \\
Phr2T & 12 & -0.021 & 0.774 & 0.758 & 0.0279 \\
Phr3B3 & 23 & 0.031 & 0.857 & 0.884 & 0.0238 \\
Phr4A10 & 34 & 0.005 & 0.936 & 0.941 & $<0.0001$ \\
Phr4G1 & 17 & 0.142 & 0.774 & 0.901 & $<0.0001$ \\
Phr7178 & 5 & 0.316 & 0.432 & 0.632 & $<0.0001$ \\
Phr756 & 9 & 0.306 & 0.510 & 0.734 & $<0.0001$ \\
Phr880 & 19 & -0.037 & 0.940 & 0.906 & 0.1331 \\
Phr4H3b & 17 & 0.059 & 0.853 & 0.907 & $<0.0001$ \\
Over all loci & $\mathbf{1 6 . 1 8}$ & $\mathbf{0 . 0 7 2}$ & $\mathbf{0 . 7 5 5}$ & $\mathbf{0 . 8 1 3}$ & $<0.0001$ \\
\hline
\end{tabular}

density circles, we can exclude the effects of genetic drift under random mating as cause ( $\mathrm{Rho}=+0.14$; p-value $=0.506$; Fig. $4 \mathrm{~B}$ ). Moreover, negative $F_{\text {IS }}$ values were associated with the lowest grasshopper density conditions and thereby with the highest genetic relatedness values $(\mathrm{Rho}=+0.62$; p-value $=0.0019 ;$ Fig. $4 \mathrm{C})$. Theoretical studies demonstrate that excess heterozygosity is expected when allelic frequencies differ in fathers and mothers (e.g. Rousset and Raymond 1995). For example, in social species negative values of $F_{\text {IS }}$ may be indicative of complicated breeding tactics rather than classical outbreeding (Van Staaden 1995) as exemplified in some populations of elephants, bats and finches (Tarr et al. 2000, Nyakaana et al. 2001, Storz et al. 2001). Since grasshoppers are often polyandrous, our result can hence be explained by the fact that most of the nymphs sampled from the lowest density circles may have emerged from a single egg-pod, where half-siblings are from a same mother but several unrelated fathers.

We detected a significant positive linear relationship between the differentiation coefficient $(\hat{a})$ and the logarithm of geographical distance at a scale $\leq 2,500 \mathrm{~m}(P<0.0001$; Fig. 5$)$. The value of the regression slope suggests that dispersal decreased strongly with geographical distance in this species (estimate [95\% confidence interval $]=0.017[0.008-0.033]$ ). Significant IBD patterns were still found when analyzing males and females separately and overlapping confidence intervals for slope estimates did not support sex-biased dispersal, at least at the nymphal stage (Fig. S5 in the Suppl. material 1). Overall, this result indicates that dispersal is seriously restricted in space at the sampled scale. This dispersal pattern is likely to limit the ability of the species to colonize new areas and can ultimately reduce the long-term persistence of the isolated populations. This is in agreement with local extinctions observed since 1996 in areas that have never been recolonized since (Foucart and Lecoq 1996, Foucart et al. 1999).

The map of the interpolated densities visually confirmed the result of the Ripley's $K$ statistics with a clear occurrence of two main high density nuclei in the northern half of the study site, while the density was very low in the southern half (Fig. 6A). An equivalent pattern was observed from the rescaled NDVI map, with highest values occurring in the northern half of the study site (Fig. 6B). The MAPI analysis also revealed a strong spatial structure, with the lowest levels of genetic differentiation observed between individu- 
A

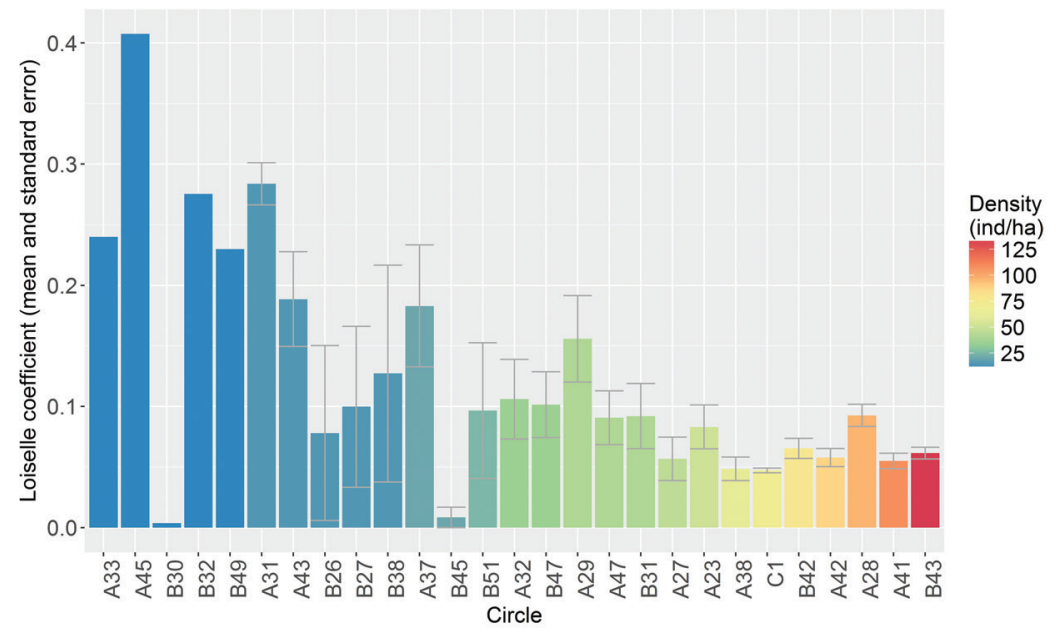

B
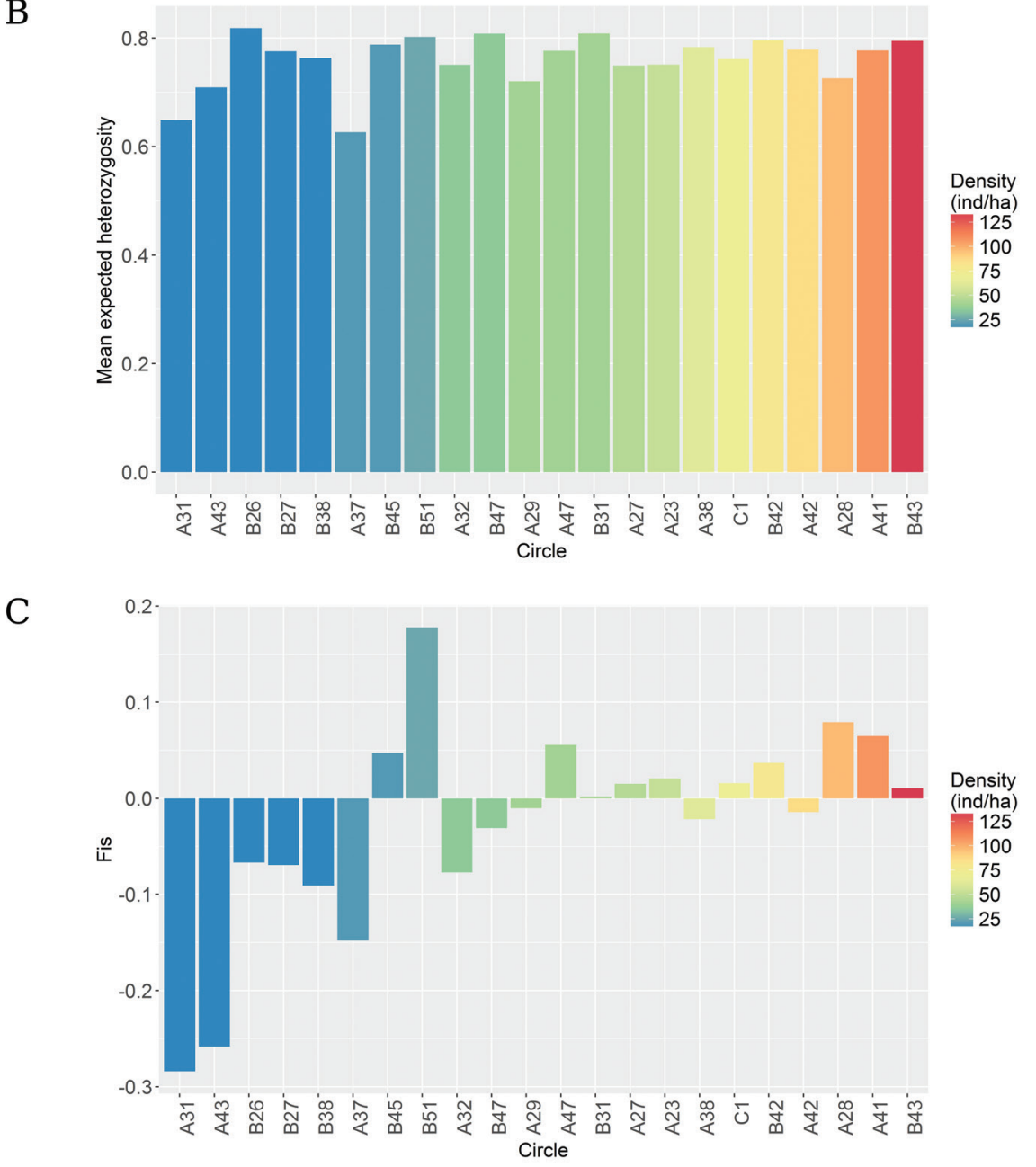

Fig. 4. Relationships between intra-circle grasshopper density and A. Loiselle kinship coefficient, B. expected heterozygosity and C. $F_{\text {IS }}$.

als located within the high density nuclei (Fig. 6C). Individuals located in lower density areas (extreme southern and northern parts of the study area) were not only differentiated from the density nuclei but also exhibited a relatively high level of differentiation across short distances. It is worth noting here that these results are expected to be robust to the observed pattern of strong IBD, even under our irregular sampling data (Piry et al. 2016). In addition, the optional parameter of minimum distance between samples in MAPI allowed us to eliminate the potential impact of the inferred presence of siblings within circles of low grasshopper density on the assessment of the surface of genetic variation. MAPI results from resampled datasets (of a maximum of 3 individuals within 


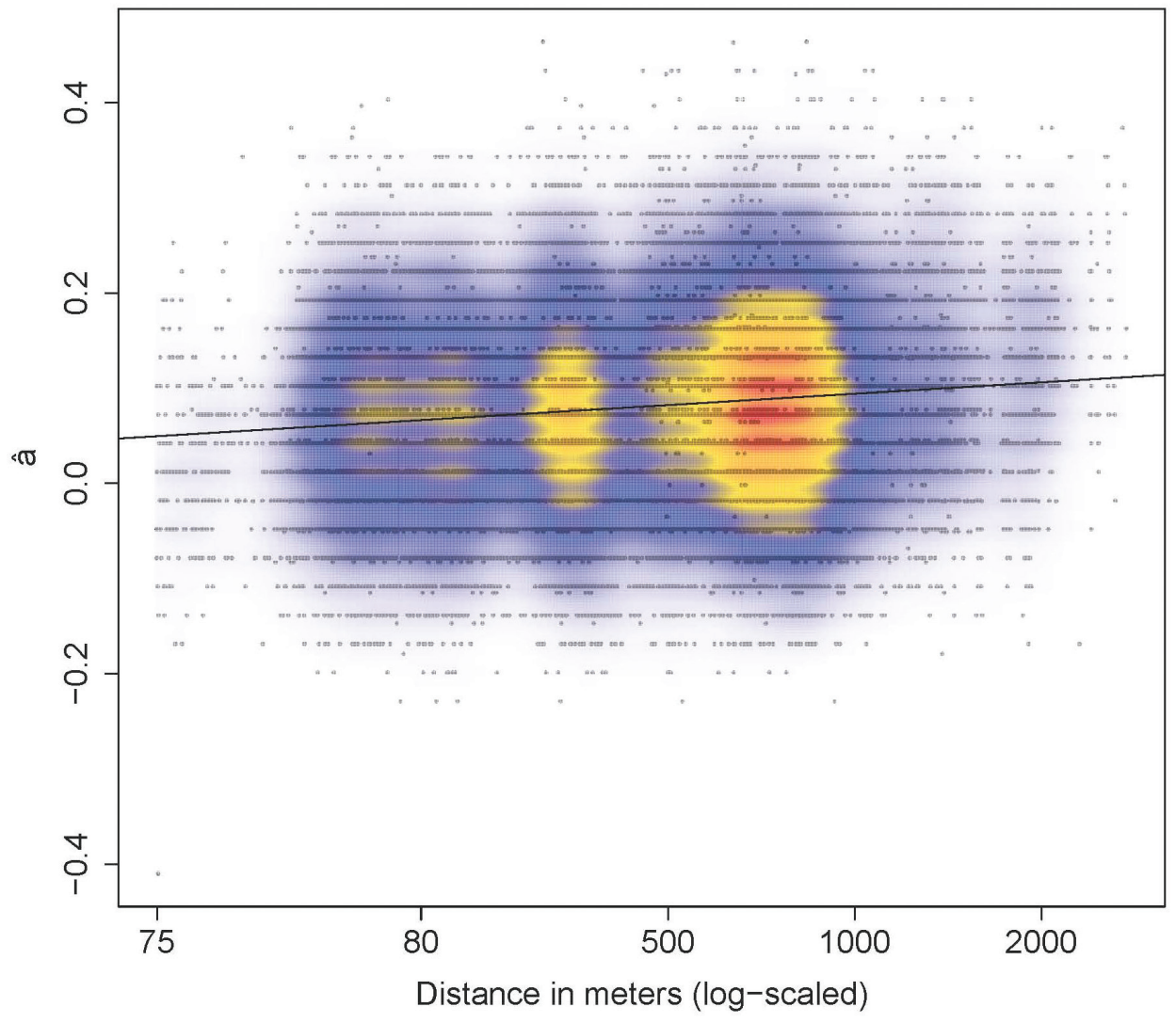

Fig. 5. Linear regression between genetic distance $\hat{a}$ and geographical distances computed between pairs of individuals. Variation in point density is represented by colors, from blue (low density) to red (high density).

circles) were highly consistent with those obtained from the complete dataset (Suppl. material 1: Fig. S8).

Finally, Spearman coefficients showed that grasshopper density and rescaled NDVI values were positively correlated (Rho $=$ 0.51 ; p-value $<2.2 \mathrm{e}^{-16}$ ) but both negatively correlated to MAPI cell values ( Rho $=-0.42$ and -0.34 , respectively; $\mathrm{p}$-value $<2.2 \mathrm{e}^{-}$ ${ }^{16}$ for both). The three cross-correlograms showed that the spatial scales of association between variables were highly similar and quite small (Fig. 7): rescaled NDVI and density values, $S p=$ $880 \mathrm{~m}\left(\mathrm{CE}_{95 \%}=[855-902]\right)$; density and MAPI cell values, $S p=859$ $\left(\mathrm{CE}_{95 \%}=[680-927]\right)$; rescaled NDVI and MAPI cell values, $S p=$ $812 \mathrm{~m}\left(\mathrm{CE}_{95 \%}=[781-850]\right)$. The strong association between values of grasshopper density, rescaled NDVI and genetic differentiation in our target site suggest that relatively subtle alterations in habitat quality can strongly impact local population dynamics by decreasing individual numbers and disrupting gene flow at a very fine scale, independently of barriers that isolate habitats. As our study area was grazed by two different flocks (see Fig. 17 in Hochkirch et al. 2014), the observed demographic and genetic patterns may be the result of a difference in grazing pressure.

This hypothesis was supported by the results of the analysis of vegetation productivity indices and NDVI in relationship with grazing treatment. Indeed, we found that three out of the four measured vegetation indices were significantly different between plots located inside and outside the fenced enclosure (Suppl. material 1: Fig. S6). The mean vegetation height and the coverage in forbs were significantly higher within the fenced enclosure (Wilcoxon test $\mathrm{p}$-value $=6.3 \mathrm{e}^{-07}$ and 0.0002 , respectively) while the coverage in bare ground was significantly lower within the fenced enclosure (Wilcoxon test p-values $=0.0001)$. No difference was observed for the coverage in dry vegetation (Wilcoxon test p-values $=0.2302$ ). The 2016-rescaled NDVI values were significantly correlated to the three productivity indices that responded to grazing. A positive correlation was found for the mean vegetation height $\left(\right.$ Rho $=0.44 ; \mathrm{p}$-value $\left.=6.4 \mathrm{e}^{-06}\right)$ and the coverage in forbs $($ Rho $=0.33 ;$ p-value $=0.0008)$ while a negative correlation was found with the coverage in bare ground ( $\mathrm{Rho}=-0.29$; $\mathrm{p}$-value $=0.004)$. Finally, the temporal analysis of the rescaled NDVI values revealed much higher values for the vegetation plots located within than outside the enclosure in May 2016, after the fencing (Wilcoxon test $\mathrm{p}$-value $<2.2 \mathrm{e}^{-16}$ ), while a slight opposite trend was found in May 2014, before the fencing (Wilcoxon test p-value = 0.0563 ) (Suppl. material 1: Fig. S7). Within the area delineated by the fenced enclosure, rescaled NDVI values associated to vegetation plots were also higher in 2016 than in 2014 (Wilcoxon test p-value $\left.<2.2 e^{-16}\right)$.

Altogether, this study suggests that $P$. rhodanica is sensitive to habitat quality and complements previous findings of a low dispersal capability at the scale of the fragmented landscape. This may explain why some subpopulations are no longer detected in the Crau Plain and imply that the few remaining ones may become extinct in the long-term as they are unlikely to be rescued through immigration. This finding emphasizes the need for managing the $P$. rhodanica population at a local scale by considering the quality of the relict habitat patches, in addition to habitat fragmentation at a larger scale (i.e. sizes of and distances between Coussoul patches). Although this study did not identify clearly the processes driving this critically endangered species to extinction, the MAPI correlative approach 
A
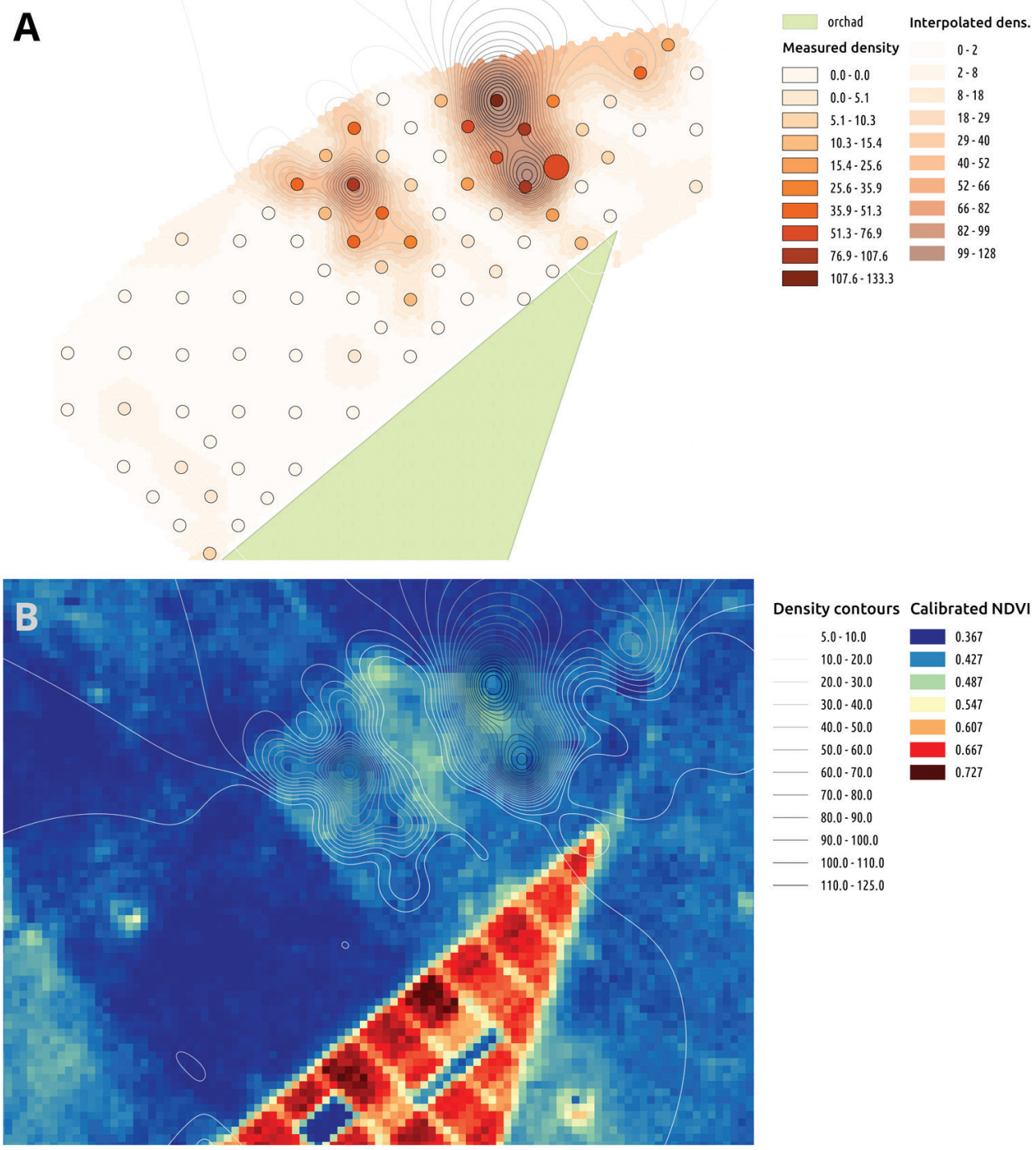

Density contours Calibrated NDVI

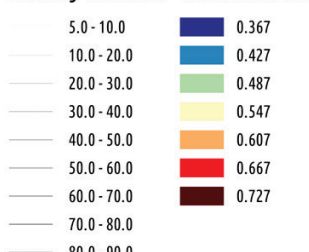

$80.0-90.0$

- $90.0 \cdot 100.0$

$-100.0 \cdot 110.0$
$-110.0 \cdot 125.0$

$-110.0 \cdot 125.0$
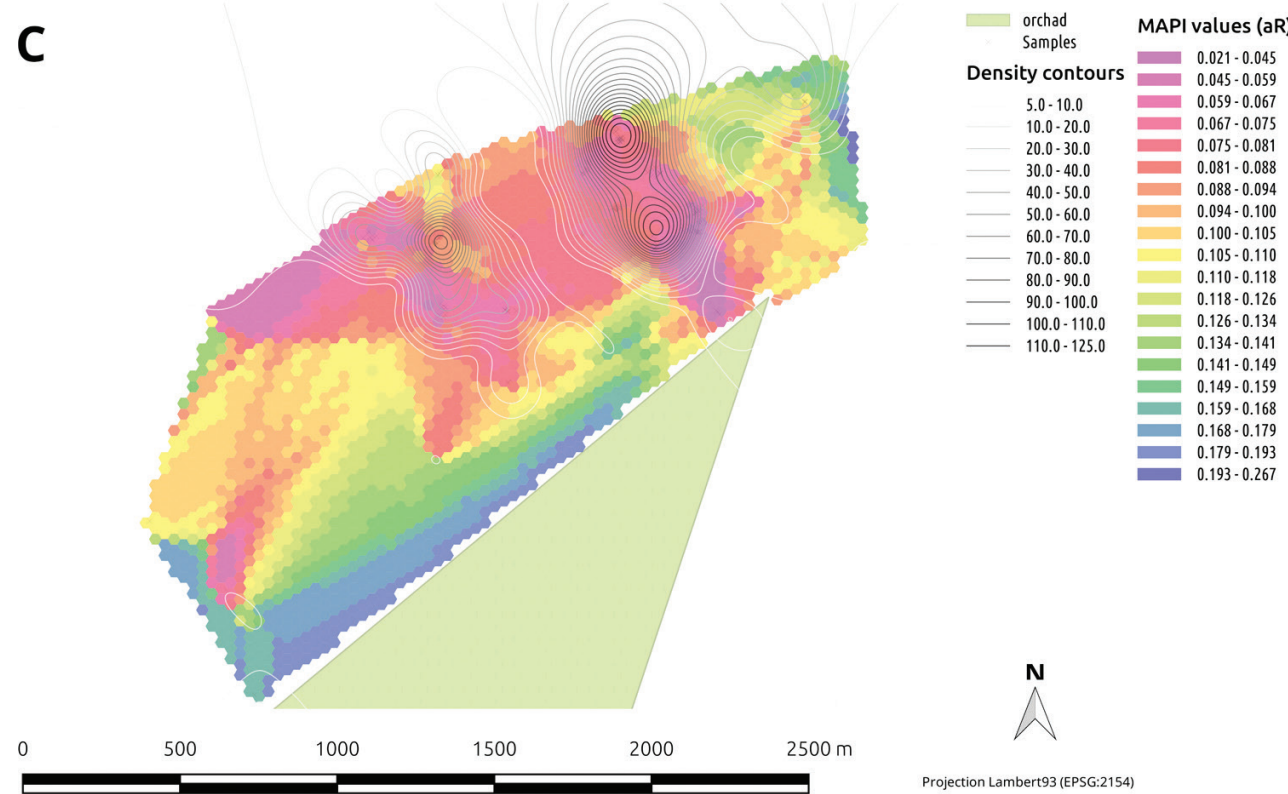

Fig. 6. Maps of A. density of grasshopper in number of individuals per hectare, B. rescale NDVI values and C. mean genetic differentiation between individuals resulting from the MAPI analysis. 

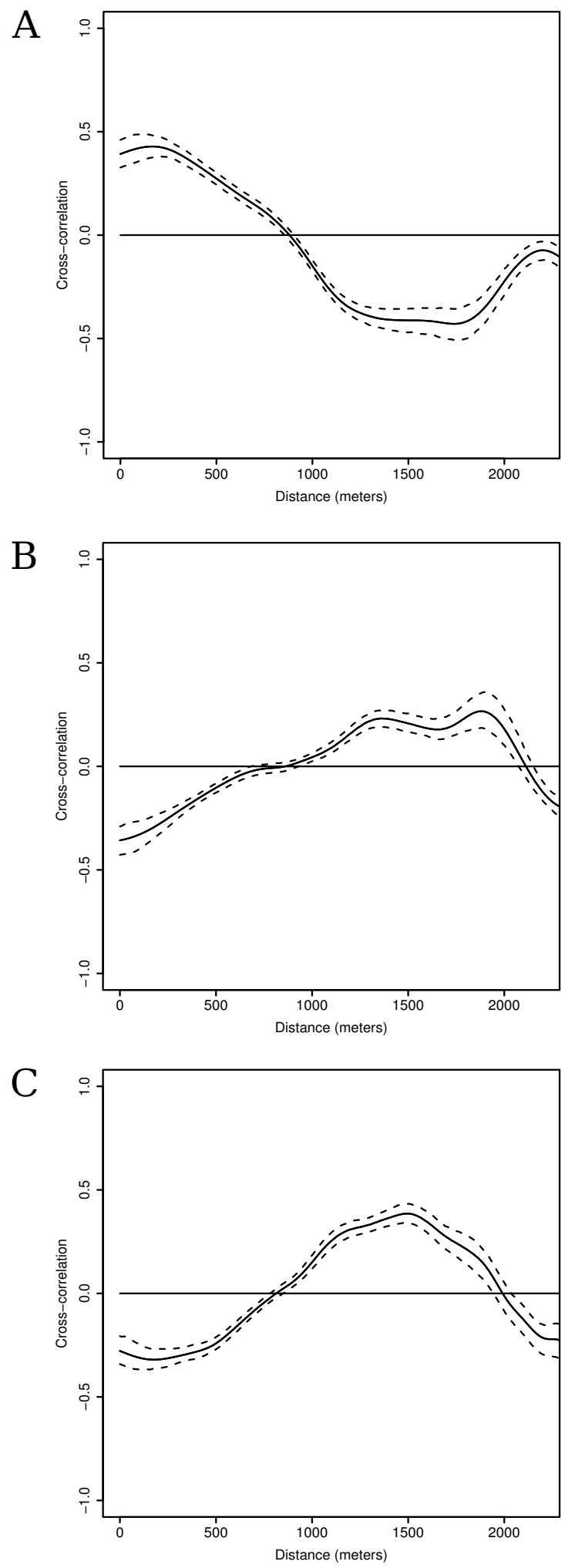

Fig. 7. Spatial cross-correlograms between A. grasshopper density and NDVI, B. grasshopper density and the mean genetic differentiation between individuals (MAPI cell values) and, C. NDVI and the mean genetic differentiation between individuals. The $x$ intercept of the spline-correlogram is the estimate of the distance at which the correlation between variables is not different than expected by chance alone. Dotted lines represent the 95\% confidence envelope based on 500 bootstrap resamples. helped us identify sheep grazing as a candidate landscape feature that may decrease grasshopper density and restrict gene flow within habitat patches. As our study was limited to a single sampling site, generalizing our results to the entire $P$. rhodanica population should be done with caution. Nonetheless, now that our indirect data-driven exploratory approach identified grazing pressure as a potential candidate driver of population decline, further work is needed in order to test for its population effects in a more direct way, draw firm conclusions and guide management actions. Above all, further fine monitoring of habitat quality (e.g. vegetation cover, structure and composition) in relation to direct measures of grazing pressure is critical. If the negative role of intense grazing is confirmed, implementing an adaptive management of pastoralism in the Crau Plain could help to sustain a higher number of reproductive grasshoppers and potential dispersers.

\section{Acknowledgements}

This work would not have been possible without the good will, motivation and curiosity of 16 persons that shared the field experiment, in addition to the authors. We want to sincerely thank each of them: Audiot P, Barrau E, Brouat C, Caizergues A. (and family), Cosson JF, Estoup A, François A, Gauthier N, Genson G, Gillon Y, Leblois R, Loiseau A, Melis JP, Pellegrin F, Perrier J. and Silvy C (in alphabetic order). They spent time, energy and sweat, walking under the sun and in the middle of aggressive stones, and we greatly appreciate it. We also thank the 'Conservatoire -Etudes des Ecosystemes de Provence' (CEEP) for help during sampling and other parts of the experiment. A special thanks to A. Guichard, who participated in the preliminary analysis of this data set during her summer training with us. This work was supported by funding from The French Institute of the Biodiversity (IFB, programme 'Biodiversity'), the French Ministry of the Territory Management and Environment (MATE, programme 'Espaces Protégés'), and the National Institute of Agronomical Research (INRA, SPE department, AIP 'génétique en temps réel').

\section{References}

Anonyme (1979) Arrêté du 3 août 1979 fixant la liste des insectes protégés en France, Abrogé par l'arrêté 1993-07-22 art. 2 JORF 24 juillet 1993. Journal officiel de la République française (Lois \& décrets).

Barker AM (2004) Insect as food for farmland birds - is there a problem? In: Van Emden H, Rothschild M (Eds) Insect and bird interactions. Intercept Ltd, Hampshire, UK, 37-50.

Berthier K (2000) Variabilité génétique de Prionotropis hystrix rhodanica: acridien emblématique de la Crau sèche soumis à la fragmentation et la réduction de son habitat. Université de Bourgogne, rapport de DEA.

Berthier K, Loiseau A, Streiff R, Arlettaz R (2008) Eleven polymorphic microsatellite markers for Oedaleus decorus (Orthoptera, Acrididae), an endangered grasshopper in Central Europe. Molecular Ecology Resources 8: 1363-1366. https://doi.org/10.1111/j.1755-0998.2008.02301.x

Besnard A, Piry S, Berthier K, Lebreton J-D, Streiff R (2007) Modeling survival and mark loss in molting animals: recapture, dead recoveries, and exuvia recoveries. Ecology 88: 289-295. https://doi. org/10.1890/05-0811

Bjørnstad ON, Falck W (2001) Nonparametric spatial covariance functions: Estimation and testing. Environmental and Ecological Statistics 8: 53-70. https://doi.org/10.1023/A:1009601932481

Blanchet E, Lecoq M, Sword GA, Berthier K, Pages C, Billot C, Rivallan R, Foucart A, Vassal J-M, Risterucci A-M, Chapuis M-P (2012) A comparative analysis of fine-scale genetic structure in three closely related syntopic species of the grasshopper genus Calliptamus. Canadian Journal of Zoology 90: 31-41. https://doi.org/10.1139/z11-109 
Blanco LJ, Aguilera MO, Paruelo JM, Biurrun FN (2008) Grazing effect on NDVI across an aridity gradient in Argentina. Journal of Arid Environments 72: 764-776. https://doi.org/10.1016/j. jaridenv.2007.10.003

Bradburd GS, Ralph PL, Coop GM (2013) Disentangling the effects of geographic and ecological isolation on genetic differentiation. Evolution 67: 3258-73. https://doi.org/10.1111/evo.12193

Buisson E, Dutoit T (2006) Creation of the natural reserve of La Crau: Implications for the creation and management of protected areas. Journal of Environmental Management 80: 318-326. https://doi. org/10.1016/j.jenvman.2005.09.013

Chapuis M-P, Loiseau A, Michalakis Y, Lecoq M, Estoup A (2005) Characterization and PCR multiplexing of polymorphic microsatellite loci for the locust Locusta migratoria. Molecular Ecology Notes 5: 554-557. https://doi.org/10.1111/j.1471-8286.2005.00987.x

Chapuis M-P, Popple JA, Simpson SJ, Estoup A, Martin JF, Steinbauer M, McCulloch L, Sword GA (2008) Eight polymorphic microsatellite loci for the Australian plague locust, Chortoicetes terminifera. Molecular Ecology Resources 8: 1414-1416. https://doi.org/10.1111/j.17550998.2008.02204.x

Chapuis M-P, Streiff R, Sword GA (2012) Long microsatellites and unusually high levels of genetic diversity in the Orthoptera. Insect Molecular Biology 21: 181-186. https://doi.org/10.1111/j.13652583.2011.01124.x

Cheylan G (1975) Esquisse écologique d'une zone semi-aride: La Crau (Bouches du Rhône). Alauda 43: 23-54.

Devaux JP, Archiloque A, Borel L, Bourrely M, Louis-Palluel J (1983) Notice de la carte phyto-écologique de la Crau (Bouches-du-Rhône). Biologie-Ecologie Méditéranéenne 10: 5-54.

Doyle JJ, Doyle JL (1987) A rapid DNA isolation procedure for small quantities of fresh leaf tissue. Phytochemical Bulletin 19: 11-15.

Foucart A (1995) Prionotropis rhodanica Uvarov, 1923 [Acridoidea, Pamphagidae, Akicerinae], acridien protégé de la Crau (Bouches-du-Rhône, France). Mémoire, Ecole Pratique des Hautes Etudes.

Foucart A, Lecoq M (1996) Biologie et dynamique de Prionotropis hystrix rhodanica Uvarov, 1923, dans la plaine de la Crau (France) (Orthoptera, Pamphagidae). Bulletin de la Société Entomologique de France 101: 75-87.

Foucart A, Lecoq M, Sieglstetter R (1999) Alarm on an endemic protected grasshopper of the Crau plain (Southern France), Prionotropis hystrix rhodanica (Orthoptera: Pamphagidae). Annales De La Societe Entomologique De France 35: 337-340.

Frankham R (2005) Genetics and extinction. Biological Conservation 126: 131-140. https://doi.org/10.1016/j.biocon.2005.05.002

Gan W, Shen H, Zhang L, Gong W (2014) Normalization of NDVI from different sensor system using MODIS products as reference. IOP Conference Series: Earth and Environmental Science 17: 012225.

Gauffre B, Mallez S, Chapuis M-P, Leblois R, Litrico I, Delaunay S, Badenhausser I (2015) Spatial heterogeneity in landscape structure influences dispersal and genetic structure: empirical evidence from a grasshopper in an agricultural landscape. Molecular Ecology 24: 1713-1728. https://doi.org/10.1111/mec.13152

GRASS Development Team (2012) Geographic Resources Analysis Support System (GRASS) Software, Version 6.4.1. Open Source Geospatial Foundation. http://grass.osgeo.org

Guillot G, Santos F (2009) A computer program to simulate multilocus genotype data with spatially auto-correlated allele frequencies. Molecular Ecology Resources 10: 1082-1084. https://doi.org/10.1111/ j.1755-0998.2008.02496.x

Hamill RM, Noor MAF, Watson ET, Ritchie MG (2006) New microsatellite loci for the European bushcricket, Ephippiger ephippiger (Orthoptera: Tettigoniidae). Molecular Ecology Notes 6: 340-342. https://doi. org/10.1111/j.1471-8286.2006.01224.x

Hardy OJ, Vekemans X (2002) SPAGeDi: a versatile computer program to analyse spatial genetic structure at the individual or population levels. Molecular Ecology Notes 2: 618-620. https://doi.org/10.1046/j.14718286.2002.00305.x
Hochkirch A, Gomboc S, Skejo J, Szovenyi G, Ivkovic S, Kristin A, Lemonnier-Darcemont M, Chobanov DP, Iorgu IS, Willemse LPM, Vedenina V, Pushkar T, Sirin D (2016) Prionotropis hystrix. The IUCN Red List of Threatened Species 2016: e.T15038381A74523729. http://dx.doi. org/10.2305/IUCN.UK.2016-3.RLTS.T15038381A74523729.en

Hochkirch A, Tatin L (2016) Prionotropis rhodanica. The IUCN Red List of Threatened Species 2016: e.T15038481A47713628. http://dx.doi. org/10.2305/IUCN.UK.2016-3.RLTS.T15038481A47713628.en

Hochkirch A, Tatin L, Stanley Price M (2014) Criquet de Crau, Une stratégie pour sa conservation 2015-2020. IUCN-SSC \& CEN PACA, Saint-Martin-de-Crau, France, 50 pp.

Karnieli A, Bayarjargal Y, Bayasgalan M, Mandakh B, Dugarjav C, Burgheimer J, Khudulmur S, Bazha SN, Gunin PD (2013) Do vegetation indices provide a reliable indication of vegetation degradation? A case study in the Mongolian pastures. International Journal of Remote Sensing 34: 6243-6262.

Keller D, Holderegger R, van Strien MJ (2013) Spatial scale affects landscape genetic analysis of a wetland grasshopper. Molecular Ecology 22: 2467-2482. https://doi.org/10.1080/01431161.2013.793865

Lange R, Durka W, Holzhauer SIJ, Wolters V, Diekotter T (2010) Differential threshold effects of habitat fragmentation on gene flow in two widespread species of bush crickets. Molecular Ecology 19: 4936-4948. https://doi.org/10.1111/j.1365-294X.2010.04877.x

Loiselle BA, Sork VL, Nason J, Graham C (1995) Spatial genetic structure of a tropical understory shrub, Psychotria officinalis (Rubiaceae). American Journal of Botany 82: 1420-1425. https://doi.org/10.2307/2445869

Nei M (1973) Analysis of gene diversity in subdivided populations. Proceedings of the National Academy of Sciences, USA 70: 3321-3323. https://doi.org/10.1073/pnas.70.12.3321

Nei M (1987) Molecular evolutionary genetics. Columbia University Press, New York.

Nyakaana S, Abe EL, Arctander P, Siegismund HR (2001) DNA evidence for elephant social behaviour breakdown in Queen Elizabeth National Park, Uganda. Animal Conservation 4: 231-237. https://doi. org/10.1017/S1367943001001275

Ortego J, Aguirre MP, Cordero PJ (2011) Fine-scale spatial genetic structure and within population male-biased gene flow in the grasshopper Mioscirtus wagneri. Evolutionary Ecology 25: 1127-1144. https://doi. org/10.1007/s10682-011-9462-1

Ortego J, Aguirre MP, Cordero PJ (2012) Landscape genetics of a specialized grasshopper inhabiting highly fragmented habitats: a role for spatial scale. Diversity and Distributions 18: 481-492. https://doi. org/10.1111/j.1472-4642.2011.00840.x

Ortego J, Garcia-Navas V, Noguerales V, Cordero PJ (2015) Discordant patterns of genetic and phenotypic differentiation in five grasshopper species codistributed across a microreserve network. Molecular Ecology 24: 5796-5812. https://doi.org/10.1111/mec.13426

Piry S, Chapuis M-P, Gauffre B, Papaïx J, Cruaud A, Berthier K (2016) Mapping Averaged Pairwise Information (MAPI): a new exploratory tool to uncover spatial structure. Methods in Ecology and Evolution 7: 1463-1475. https://doi.org/10.1111/2041-210X.12616

Prevedello JA, Vieira MV (2010) Does the type of matrix matter? A quantitative review of the evidence. Biodiversity and Conservation 19: 1205-1223. https://doi.org/10.1007/s10531-009-9750-z

R Core Team (2015) R: A Language and Environment for Statistical Computing. http://www.R-project.org.

Raynolds M, Magnússon B, Metúsalemsson S, Magnússon SH (2015) Warming, sheep and volcanoes: land cover changes in Iceland evident in satellite NDVI trends. Remote Sensing 7: 9492-9506. https://doi. org/10.3390/rs70809492

Reinhardt K, Kohler G, Maas S, Detzel P (2005) Low dispersal ability and habitat specificity promote extinctions in rare but not in widespread species: the Orthoptera of Germany. Ecography 28: 593-602. https:// doi.org/10.1111/j.2005.0906-7590.04285.x

Romermann C, Dutoit T, Poschlod P, Buisson E (2005) Influence of former cultivation on the unique Mediterranean steppe of France and consequences for conservation management. Biological Conservation 121: 21-33. https://doi.org/10.1016/j.biocon.2004.04.006 
Rousset F, Raymond M (1995) Testing heterozygote excess and deficiency. Genetics 140: 1413-1419.

Rousset F (2000) Genetic differentiation between individuals. Journal of Evolutionary Biology 13: 58-62. https://doi.org/10.1046/j.14209101.2000.00137.x

Rousset F (2008) GENEPOP'007: a complete re-implementation of the GENEPOP software for Windows and Linux. Molecular Ecology Resources 8: 103-106. https://doi.org/10.1111/j.14718286.2007.01931.x

Sardet E, Defaut B (2004) Les orthoptères menacés en France. Liste rouge nationale et listes rouges par domaines biogéographiques. Matériaux Orthoptériques et Entomocénotiques 9: 125-137.

Storey JD, Tibshirani R (2003) Statistical significance for genome-wide studies. Proceedings of the National Academy of Sciences, USA 100: 9440-9445. https://doi.org/10.1073/pnas.1530509100

Storz JF, Bhat HR, Kunz TH (2001) Genetic consequences of polygyny and social structure in an Indian fruit bat, Cynopterus sphinx. I. Inbreeding, outbreeding, and population subdivision. Evolution 55: 1215-23. https://doi.org/10.1111/j.0014-3820.2001.tb00641.x

Streiff R, Audiot P, Foucart A, Lecoq M, Rasplus JY (2005) Genetic survey of two endangered grasshopper subspecies, Prionotropis hystrix rhodanica and Prionotropis hystrix azami (Orthoptera, Pamphagidae): within- and between-population dynamics at the regional scale. Conservation Genetics 7: 331-344. https://doi.org/10.1007/ s10592-005-9043-3

Streiff R, Mondor-Genson G, Audiot P, Rasplus J-Y (2002) Microsatellite DNA markers for a grasshopper: Prionotropis hystrix rhodanica (Orthoptera, Pamphagidae). Molecular Ecology Notes 2: 265-267. https://doi. org/10.1046/j.1471-8286.2002.00218.x

Tarr CL, Ballou JD, Morin MP, Conant S (2000) Microsatellite variation in simulated and natural founder populations of the Laysan finch (Telespiza cantans). Conservation Genetics 1: 135-146. https://doi. org/10.1023/A: 1026530905410

Tatin L, Wolff A, Boutin J, Colliot E, Dutoit T (2013) Ecologie et conservation d'une steppe méditerranéenne, la plaine de Crau. Quae editions, Versailles, France, 384 pp.

Van Staaden MJ (1995) Breeding tactics, social structure and genetic variation in mammals. Acta Theriologica 3: 165-182. https://doi. org/10.4098/AT.arch.95-54
Watts PC, Rousset F, Saccheri IJ, Leblois R, Kemp SJ, Thompson DJ (2007) Compatible genetic and ecological estimates of dispersal rates in insect (Coenagrion mercuriale: Odonata: Zygoptera) populations: analysis of 'neighbourhood size' using a more precise estimator. Molecular Ecology 16: 737-751. https://doi.org/10.1111/j.1365-294X.2006.03184.x

Weir BS, Cockerham CC (1984) Estimating F-statistics for the analysis of population structure. Evolution 38: 1358-1370.

Wolff A, Paul JP, Martin JL, Bretagnolle V (2001) The benefits of extensive agriculture to birds: the case of the little bustard. Journal of Applied Ecology 38: 963-975. https://doi.org/10.1046/j.13652664.2001.00651.x

Wolff A, Dieuleveut T, Martin J-L, Bretagnolle V (2002) Landscape context and little bustard abundance in a fragmented steppe: implications for reserve management in mosaic landscapes. Biological Conservation 107: 211-220. https://doi.org/10.1016/S0006-3207(02)00087-3

Wolff A, Tatin L, Dutoit T (2013) La Crau, une steppe méditérranéeenne unique en France? In Tatin L, Wolff A, Boutin J, Colliot E, Dutoit T (Eds) La Crau, Ecologie et conservation d'une steppe méditérranéenne: la plaine de Crau, Editions Quae, Paris, $352 \mathrm{pp}$.

Zhang D-X, Yan L-N, Ji Y-J, Kang L, Hewitt GM, Huang Z-S (2003) Isolation, characterization and cross-species amplification of eight microsatellite DNA loci in the migratory locust (Locusta migratoria). Molecular Ecology Notes 3: 483-486. https://doi.org/10.1046/j.1471-8286.2003.00485.x

\section{Supplementary material 1}

Authors: Sylvain Piry, Karine Berthier, Réjane Streiff, Sandrine Cros-Arteil, Antoine Foucart, Laurent Tatin, Linda Bröder, Axel Hochkirch, Marie-Pierre Chapuis

Data type: MS Word document

Explanation note: Supplementary tables and figures.

Copyright notice: This dataset is made available under the Open Database License (http://opendatacommons.org/licenses/ odbl/1.0/). The Open Database License (ODbL) is a license agreement intended to allow users to freely share, modify, and use this Dataset while maintaining this same freedom for others, provided that the original source and author(s) are credited.

Link: https://doi.org/10.3897/jor.27.15036.suppl1 